\title{
KUALITAS INFORMASI DAN KEAMANAN TRANSAKSI FAKTOR KUNCI PENUNJANG PERKEMBANGAN E-COMMERCE
}

\author{
Asep Lucky Resa \\ Universitas Pendidikan Indonesia \\ Asep.lucky@student.upi.edu \\ Lili Adi Wibowo \\ Universitas Pendidikan Indonesia \\ Liliadiwibowo@upi.edu
}

\begin{abstract}
Purpose - The purpose of this paper was to be found out the influence factors of the dominant country of origin against purchasing decisions on local brand

Design/methodology/approach - the design of the research was a cross-sectional design. This research used verification approach with survey method. A total of 200 respondents were chosen as using non probability sampling. A survey questionnaire was used as a research instrument to collect the data from respondents. The analysis technique used SEM analysis tools'

Findings - Quality of information and transaction security has influenced on purchase decisions online simultaneously and partially.

Originality/value - The paper provides a basis to understand the issues of purchasing decisions on local brand in Indonesia. The difference of this study with earlier research on objects that are the variable used supporting the theory as well as the different references used by previous researchers.
\end{abstract}

Keywords: country of origin, purchase decisions

Article Type : Research Paper

\section{PENDAHULUAN}

Indonesia yang terdiri atas 13.466 gugusan pulau dan memiliki 1340 suku bangsa menjadi negara yang sangat potensial dalam sektor pariwisata (Badan Pusat Statistik 2010). Hingga 2015 sektor pariwisata telah menyumbangkan lebih dari $\$ 9$ Miliar dolar untuk pendapatan negara dan menempati posisi ke 4 dari total pendapatan ekspor barang dan jasa. Objek pariwisata di Indonesia umumnya dikelompokkan menjadi empat yaitu wisata budaya, wisata keagamaan, wisata belanja, dan wisata alam atau outdoor.

Berdasarkan laporan American Express Retail Network pada tahun 2012 wisata alam bernuansa petualang semakin menjadi sorotan masyarakat dan menjadi pilihan berwisata. Wisata alam yang sangat popular di Indonesia adalah pendakian gunung. Kegiatan pendakian gunung menjadi aktifitas yang cukup digemari banyak orang, baik dari kalangan muda ataupun dikalangan tua. Kegiatan dialam bebas seperti mendaki gunung ini bisa dikatakan sebagai olahraga rekreasi, akan tetapi karena aktifitas ini dilakukan dialam terbuka, maka kegiatan pendakian gunung membutuhkan kesiapan seperti pengetahuan tentang kegiatan alam bebas (teknis pendakian gunung) tentunya mental dan fisik yang prima dari para pendaki tersebut kemudian peralatan yang layak dan memadai. Kegiatan outdoor membutuhkan peralatan khusus seperti carabiner dan harness untuk kegiatan panjat tebing, jaket khusus, sepatu gunung dan juga termasuk yang paling penting adalah tas gunung (carrier). Penelitian yang dilakukan oleh The Association of Self-Reported Backpack Heuscher, (Heuscher, Gilkey, Peel, \& Kennedy, 2010) mengungkapkan bahwa pemilihan tas gunung sangat penting terutama untuk kesehatan pengguna. Tas gunung yang tidak sesuai standar akan mempengaruhi kesehatan tubuh pengguna karena jika dibandingkan dengan tas biasa tas gunung mempunyai peranan penting dalam membawa banyak kebutuhan pendaki. Produsen mendesain tas sedemikian rupa sehingga dapat membantu punggung dalam menyangga beban saat tas digendong. Keadaan tersebut mendorong persaingan antar produsen tas baik itu lokal maupun luar negeri. Persaingan dalam dunia bisnis hampir terjadi pada seluruh industri (Rahayu \& Anggarini, 2009)

Perilaku konsumen Indonesia yang lebih menyukai produk tas gunung luar negeri, selain di nilai dari kualitas juga beranggapan bahwa produk tas gunung luar negeri merupakan barang yang bisa dibanggakan sehingga lebih percaya diri saat menggunakannya dan berhubungan pada gaya hidup serta komunitas. Apabila seseorang menggunakan 
produk ternama dari luar, konsumen akan merasa mendapatkan pengakuan lebih dari komunitasnya. Sejalan dengan kondisi tersebut, dapat dipastikan akan banyak pemain baik yang sudah ada maupun baru masuk ke Indonesia, yang melihat potensi besar untuk menumbuhkan bisnis di Indonesia. (Lisnawati, 2016).

Menurut penelitian yang dilakukan oleh (Jiménez \& Martín, 2012) mengemukakan faktor lain yang menyebabkan seseorang lebih menyukai tas gunung luar juga adalah bahwa konsumen sudah memiliki kepercayaan yang tinggi terhadap produk tersebut dan sudah tahu bahwa produsen atau negara pembuat tas gunung tersebut adalah negara maju yang sudah terkenal handal dan dipercaya mampu menciptakan produk yang berkualitas sangat tinggi. Akhirnya ketika muncul produk tas gunung lokal konsumen susah untuk merespon hal tersebut. Country of Origin (COO) diidentifikasi sebagai faktor yang berpengaruh pada daya saing internasional (D, Deilami, \& Ma, 2013)

Penelitian tersebut didukung oleh yang mengungkapkan bahwa konsumen lokal suatu Negara lebih menyukai produk luar. Konsumen menggunakan status produk sebagai simbol untuk mengkomunikasikan kepada kelompok referensi yang responnya sangat penting bagi pemakai produk (Diamantopoulos, Schlegelmilch, \& Palihawadana, 2011). Konsumen cenderung mempunyai pertimbangan-pertimbangan tertentu dalam membeli sebuah produk di mana pertimbangan tersebut didasarkan pada kualitas produk dan harga(Lin \& Chen, 2006). Faktor lain, persaingan antar merek menjadi semakin tinggi dan kompleksitasnya sejalan dengan meningkatnya merek dari luar negeri (Kim \& Chung, 1997). Menurut (D et al., 2013) COO menggambarkan bagaimana konsumen mempersepsikan produk yang berasal dari suatu negara tertentu.

Adanya produk-produk impor dapat mempengaruhi konsumen domestik dalam membeli produk karena dengan bertambahnya produk yang masuk dari luar negeri dapat menimbulkan perubahan pada niat pembelian produk-produk lokal $(\mathrm{Hu}, \mathrm{Li}$, Xie, \& Zhou, 2008). Citra suatu negara asal atau country of origin image berpengaruh kepada penerimaan konsumen, perilaku, dan niat untuk membeli. Hal ini sering digunakan oleh individu untuk mengevaluasi suatu produk yang akan dibeli (Acharya \& Elliot 1998). Pendapat yang sama dikemukakan oleh Hong dan Wyer (1989) mengatakan bahwa pada saat konsumen melakukan evaluasi akan barang asing, konsumen akan memakai citra negara asal sebagai informasi. Bagi sebagian individu, negara asal suatu produk merupakan suatu hal yang sangat penting. Menurut (Hu et al., 2008) citra negara asal sering dipertimbangkan sebagai suatu faktor yang dapat memengaruhi konsumen.

Penelitian yang dilakukan oleh (Hu et al., 2008) di China, mendapatkan temuan bahwa masyarakat China dalam mengkonsumsi suatu produk, mereka lebih memilih produk luar yang sudah mereka percaya dan mereka ketahui sebagai produk yang mempunyai kualitas baik. Terungkap bahwa masyarakat China malu apabila mengkonsumsi produk negaranya sendiri walaupun di China terdapat pembatasan impor barang.

Beberapa penulis mengkonseptualisasikan COO sebagai negara dimana produk diproduksi dan dikaitkan dengan negara tertentu (Parameswaran dan Pisharodi, 1994; Thakor dan Katsanis, 1997 dalam Muchtar et al., 2012; Johansson et al., 1985; Ozsomer dan Cavusgil, 1991 dalam Al-Sulaiti dan Baker, 1998). Secara khusus, Archarya dan Elliott (2001) serta Wong et al. (2008) menyatakan bahwa COO menggambarkan negara dimana produk atau Fkomponen produk dirakit, diproduksi, atau didesain, sedangkan Ahmed dan d'Astou menggambarkan $\mathrm{COO}$ sebagai negara dimana produk diproduksi atau dirakit.

Masyarakat yang mengkonsumsi barang atau jasa memiliki alternatif pilihan lain dalam membeli produk yang sudah mereka percaya (The Effect of Brand Awarness) yang menyebabkan orang akan memilih produk yang sudah mereka kena, Dengan kata lain bahwa merek memiliki nilai atau ekuitas merek bagi suatu perusahaan(Ihya Ulumuddin, Lili Adi Wibowo, 2013). Menurut (Piron \& Francis, 2000) Evaluasi yang dilakukan konsumen atas suatu produk tertentu tidak hanya didasarkan pada daya tarik karakteristik produk fisik saja, tetapi juga berdasarkan negara yang memproduksinya (country of origin).

Negara asal suatu produk menjadi sangat penting untuk konsumen, sehingga konsumen dapat mempertimbangkan untuk memutuskan membeli atau sebaliknya. Sebagian besar masyarakat negara berkembang khususnya Indonesia masih menganggap produk negara luar lebih baik daripada buatan dalam negeri, seperti pada produk tas gunung. Berdasarkan penelitian yang dilakukan oleh Mahestu (2007) bahwa country of origin akan menciptakan suatu persepsi tertentu terhadap suatu produk, bisa positif maupun negatif.

Persepsi masing-masing individu di setiap negara cenderung berbeda-beda terhadap seberapa penting dampak country of origin bagi keputusan pembelian yang mereka lakukan. Implikasinya, reputasi suatu negara dapat berbeda-beda di setiap negara dan dapat berubah seiring perubahan waktu. Berdasarkan uraian tersebut dapat diketahui bahwa ternyata persepsi konsumen tentang negara asal suatu merek sangatlah penting dalam menimbulkan keputusan pembelian suatu produk terutama produk lokal yang dimata konsumen masih dianggap kalah saing dengan produk dari luar negeri sehingga minat beli dan keputusan pembeliannya rendah.

Tujuan penelitian ini adalah: (1) memperoleh temuan mengenai gambaran faktor-faktor country of origin, (2) memperoleh temuan mengenai gambaran country of origin dan keputusan pembelian, (3) memperoleh temuan mengenai pengaruh faktorfaktor dominan country of origin terhadap keputusan pembelian.

\section{KAJIAN PUSTAKA}

Konsumen pada saat membuat keputusan pembelian, akan dihadapkan pada sebuah proses. Proses keputusan pembelian dimulai jauh sebelum benar-benar membeli dan berlanjut jauh setelahnya. Tahapan yang dilalui konsumen pada saat dihadapkan 
pada proses pengambilan keputusan dapat dijadikan sebagai tolak ukur untuk memahami perilaku pembelian konsumen pada saat sebelum, ketika dan setelah melakukan pembelian. Karakteristik konsumen dan proses pengambilan keputusan akan mempengaruhi keputusan pembelian yang diambil oleh masing-masing individu.

Tahap pertama yang akan dilalui oleh konsumen ialah pengenalan kebutuhan, jika telah mengetahui apa yang dibutuhkan kemudian konsumen mencari informasi untuk memenuhi kebutuhannya tersebut. Setelah mendapatkan berbagai informasi mengenai kebutuhannya, maka konsumen akan dihadapkan pada pilihan mengenai produk dan jasa yang dapat memenuhi kebutuhannya, beserta dengan pilihan alternatif jika tidak ada produk atau jasa yang sesuai dengan keinginan dan kebutuhannya. Jika sudah memiliki pilihan yang sesuai dengan kebutuhan, maka konsumen siap membuat keputusan pembelian. Tahapan terakhir pada proses ini ialah perilaku konsumen setelah melakukan pembelian, yaitu menggunakan atau membuang dan mengevaluasi produk dan jasa yang telah dibeli dan digunakan karena konsumen harus mengulangi tahapan pembelian untuk mengetahui apakah produk dan jasa yang telah dibelisudah memenuhi kebutuhan dan harapan atau tidak, apabila tidak apakah ada alternatif lain sebagai pengganti produk dan jasa tersebut yang lebih baik lagi. Pemahaman mengenai perilaku konsumen dalam konteks ketidakpuasan jauh lebih mendalam dari konteks kepuasan konsumen (Lili Adi Wibowo dan Yeni Yuniawati, 2007)

Howard dalam et al.(2012:551) mengemukakan pendapatnya mengenai dimensi yang mempengaruhi keputusan pembelian yang terdiri dari enam variabel, diantaranya adalah Information (Informasi), Brand Recognition (Pengenalan Merek), Brand Attitude (Sikap Merek), Faith (Keyakinan), Purchase Willingness (Kesediaan Membeli). Proses pengambilan keputusan pelanggan kadang-kadang bisa menjadi proses yang rumit dan pelanggan dapat mengandalkan informasi tentang produk dan merek dan pengalaman pelanggan mereka berkumpul mencapai pembuatan keputusan pembelian.(Wibowo, 2014)

Salah satu faktor yang nmempengaruhi interpretasi dalam tahapan persepsi konsumen pada suatu produk adalah country of origin. Konsumen cenderung akan mengingat suatu barang dengan asal negara tertentu, dan hal ini menjadi keuntungan tersendiri bagi produk yang terasosiasi di benak konsumen ketika konsumen hanya memiliki informasi lokasi suatu produk dihasilkan, maka dalam pengambilan keputusan pembelian akan di pengaruhi oleh persepsi konsumen akan negara tersebut. Masuknya produk-produk asing ke suatu negara dengan strategi modal ventura, investasi secara langsung maupun lisensi sebagai salah satu efek dari pasar terbuka maka akan semakin berkurang juga produk-produk buatan luar negeri dan tentu saja di beberapa negara muncul efek country of origin yang mempengaruhi persepsi konsumen terhadap kualitas produk tersebut (kaynak dan kara, 2002). Dalam penelitian ini, dimensi-dimensi berikut dijadikan beberapa indikator yang bisa diukur, diantaranya country beliefs, people affect dan desired interaction merupakan pendapat Kotler (1993), Laroche et,al., (2005) dan Yasin et,al., (2007), dalam Listiana (2012). Hasil penelitian mengungkapkan bahwa country of origin memiliki beberapa dimensi yaitu economics development level, living standard, technology developing level, product quality, self-confident level for owning this product, product reliability. Pendapat tersebut merupakan hasil penelitian yang dilakukan oleh Han and Terpstra (1988) dalam Nagashima's (1970) yang telah disempurnakan Chens (2000) dalam Long-Yi Lin and Chun-Shuo Che (2006:254).

Gambar 1 Paradigma Penelitian

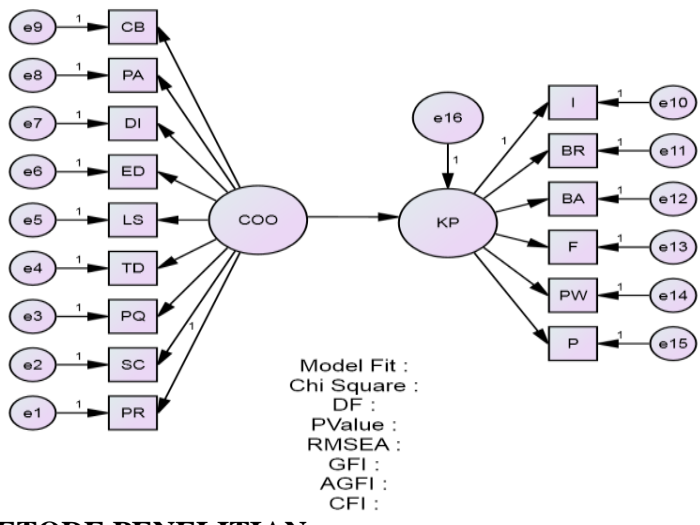

\section{METODE PENELITIAN}

Penelitian ini dilakukan untuk mengetahui pengaruh country of origin terhadap keputusan pembelian pada tas gunung lokal. Variabel bebas (independent variable) atau variabel eksogen yang terdapat pada penelitian ini yaitu country of origin dengan dimensi country beliefs, people affect dan desired interaction economics development level, living standard, technology developing level, product quality, self-confident level for owning this product, product reliability. sedangkan variabel terikat (dependent variable) atau variabel endogen pada penelitian ini yaitu keputusan pembelian dengan dimensi Information (Informasi), Brand Recognition (Pengenalan Merek), Brand Attitude (Sikap Merek), Faith (Keyakinan), Purchase Willingness (Kesediaan Membeli).

Objek/unit analisis pada penelitian ini yaitu konsumen tas gunung buatan Indonesia. Penelitian ini dilakukan pada kurun waktu kurang dari satu tahun, sehingga teknik pengumpulan data yang digunakan pada penelitian ini adalah cross-sectional method. Teknik yang digunakan dalam penelitian ini adalah teknik propability yaitu simple random dengan jumlah sampel sebanyak 200 konsumen. Teknik pengumpulan data yang digunakan adalah studi kepustakaan, studi lapangan dengan penyebaran kuesioner secara online, dan studi literatur. Sedangkan teknik analisis data yang dilakukan adalah analisis deskriptif dan verifikatif. Analisis data verifikatif menggunakan SEM dengan bantuan software SMOS 20.0 for windows. 


\section{HASIL PENELITIAN DAN PEMBAHASAN}

Pengujian hipotesis penelitian ini dilakukan untuk mengetahui besarnya pengaruh country of origin terhadap keputusan pembelian. Pengujian hipotesis secara simultan dilakukan menggunakan teknik analisis Structure Equation Model (SEM). Hipotesis penelitian ini adalah country of origin berpengaruh secara simultan dan parsial terhadap keputusan pembelian. Hipotesis ini diuji secara simultan maupun parsial dengan menggunakan AMOS 20.0 for windows. Hasil pengujian hipotesis secara keseluruhan (simultan) dapat dilihat berdasarkan fariabel faktor-faktor country of origin memiliki pengaruh langsung terhadap keputusan pembelian sebesar 0.959. Secara keseluruhan model konseptual persamaan struktural yang dirancang berdasarkan goodness of fit atau pengujian model penelitian memenuhi kelayakan model (fit) yang berarti sesuai dengan kondisi empiris. maka dapat diambil keputusan bahwa hipotesis nol $\left(\mathrm{H}_{0}\right)$ ditolak dan $\mathrm{H}_{\mathrm{i}}$ diterima, sehingga dapat dikatakan bahwa terdapat hubungan linear antara faktor-faktor pembentuk country of origin terhadap keputusan pembelian. hipotesis penelitian dinyatakan diterima, karena sesuai dengan kriteria penerimaan hipotesis yaitu nilai Critical Ratio (C.R.) $\geq 1,967$ atau nilai probabilitas $(\mathrm{P}) \leq 0,05$ maka $\mathrm{H}_{0}$ ditolak (hipotesis penelitian diterima).

Hasil pengujian secara keseluruhan memberikan hasil yang signifikan. Maka untuk mengetahui dimensi $\mathrm{X}$ yang berpengaruh terhadap pembentukan $\mathrm{Y}$, maka dapat dilanjutkan dengan pengujian secara parsial. Dengan membandingkan setiap goodness of fit dengan nilai probability 0,030, nilai RMSEA $0,032 \leq 0,08$, nilai GFI 0,983 $\geq 0,90$, nilai AGFI $0,967 \geq 0,90$, nilai CFI $0,998 \geq 0,90$.

Hasil yang diperoleh menunjukkan bahwa semua taksiran parameter pada diagram jalur tersebut adalah signifikan.

Berdasarkan hasil perhitungan diatas, maka dapat digambarkan diagram jalur dari hipotesis pada penelitian sebagai berikut:

Gambar 2 Diagram Jalur Pengujian Hipotesis

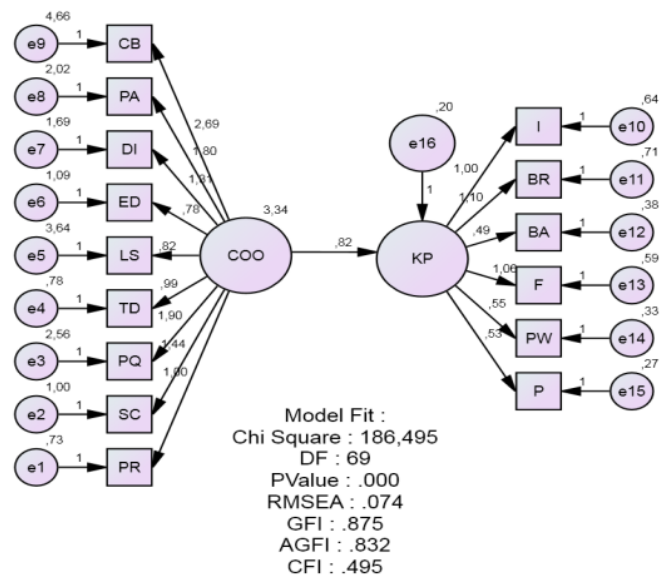

Melalui gambar diagram jalur besarnya pengaruh masing-masing variabel laten secara langsung (standardize direct effect) maupun tidak langsung (standardize indirect effect) serta efek total (standardizes total effect) bahwa variabel faktorfaktor country of origin memiliki pengaruh langsung terhadap keputusan pembelian sebesar 0.959. Secara keseluruhan model konseptual persamaan struktural yang dirancang berdasarkan goodness of fit atau pengujian model penelitian memenuhi kelayakan model (fit) yang berarti sesuai dengan kondisi empiris.

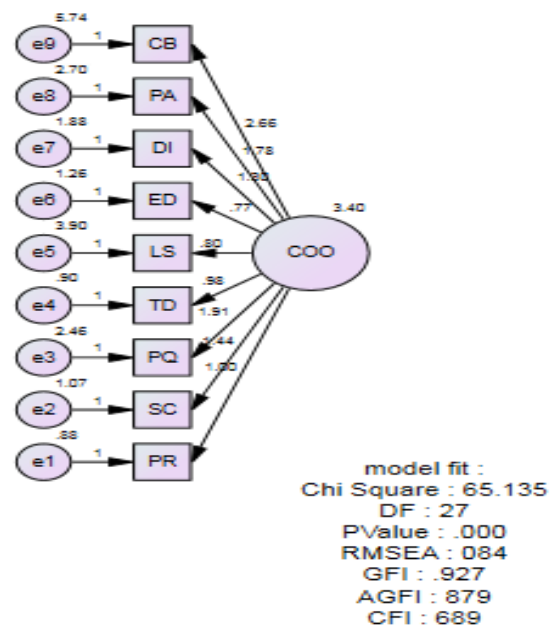

Pengujian dan perhitungan secara parsial dapat dilihat melalui tabel standardized regresion weights spada hasil AMOS. Dari hasil perhitungan menggunakan AMOS, menunjukan nilai bobot dimensi dalam membentuk country of origin. Dimensi Self-Confident for owning this product merupakan dimensi yang memiliki pengaruh yang tinggi yaitu sebesar 0.931 dan dimensi yang memiliki nilai paling rendah yaitu living standard yaitu 0.6.00.

Berdasarkan model penelitian, faktor-faktor country of origin positif terhadap keputusan pembelian dapat dilakukan perhitungan untuk mengetahui pengaruh langsung dan tidak langsung antara dimensi-dimensi. Country of origin memiliki peran penting dalam persepsi konsumen terhadap produk dan merek dari negara tertentu (Bilkey dan Nes,1982; Johansson et al,1985; Saeed, 1994; Ahmed et al, 2004), yang selanjutnya mempengaruhi keputusan pembelian (Roth dan Romeo., 1992; Papadopoulos dan Heslop, 1993). Hong dan Wyer ( 1989) menemukan bahwa country of origin bisa langsung mengerahkan dampak positif pada evaluasi kualitas produk konsumen. Han (1989) menunjukkan bahwa ketika konsumen tidak akrab dengan produk atau merek, mereka bergantung pada efek promosi yang secara tidak langsung dapat mempengaruhi produk konsumen ketika menyimpulkan produk atribut merek. Sedangkan ketika mereka akrab dengan produk/merek, mereka meringkas keyakinan mereka mengenai produk/merek atribut dan ringkasan membangun ini secara langsung mempengaruhi sikap konsumen terhadap produk/merek. Country of Origin merupakan negara asal produk dihasilkan. Untuk menunjukkan Country Of Origin (COO) 
seringkali ditulis kata "made in" pada kemasan produk. Banyak orang kemudian sangat familiar dengan kata "made in" sehingga ketika meliahat kata "made in" pada produk kemasan, mereka langsung mengartikan produk tersebut berasal dari negara tertentu. Misalkan jika pada kemasan produk tertulis "made in USA", mereka akan mengartikan produk tersebut berasal dari Amerika Serikat (Keegan, 2007).

Berdasarkan hasil penelitian ditemukan teori yang berupa pengaruh country of origin terhadap keputusan pembelian yang didukung oleh pendapat Long-Yi Lin and Chun-Shuo Chen (2006:261) mengatakan bahwa "country of origin image has a significantly positive influence on consumer purchase decision". Berdasarkan kutipan tersebut menjelaskan bahwa negara asal berpengaruh positif terhadap keputusan pembelian. Pendapat yang sama dikemukakan oleh Hong dan Wyer (1989) mengatakan bahwa pada saat konsumen melakukan evaluasi akan barang asing, konsumen akan memakai citra negara asal sebagai informasi. Bagi sebagian individu, negara asal suatu produk merupakan suatu hal yang sangat penting. Menurut Baughn \& Yaprak (1993), Bilkey \& Nes (1982), Liefeld, (1993), Ozsomer \& Cavusgil (1991), Samiee (1994), citra negara asal sering dipertimbangkan sebagai suatu faktor yang dapat memengaruhi keputusan pembelian konsumen.

Berdasarkan temuan empiris pada penelitian ini menunjukan bahwa country of origin adalah faktor yang menjadi pertimbangan dalam membentuk keputusan pembelian. Secara berurutan dimensi yang berpengaruh pada country of origin adalah self-confident level for owning this product, product quality, country beliefs, people affect, product reliability, technology developing level,desired interaction, economic development level, living standard. Temuan ini berbeda dengan penelitian-penelitian sebelumnya yang hanya menemukan pengaruh saja bukan menemukan dimensi yang berpengaruh lebih signifikan yang membentuk country of origin dampaknya terhadap keputusan pembelian. Berdasarkan hasil penelitian yang bersifat empiris mengenai country of origin, didapat bahwa dimensi self confident for owning this product memiliki skor yang paling besar.

Temuan empiris pada penelitian ini menunjukan bahwa keputusan pembelian berada pada kategori yang cukup tinggi. Secara berurutan dimensi yang membangun keputusan pembelian adalah faith, brand recognition, informasi, purchase, purchase willingness, dan brand attitude. Berdasarkan hasil penelitian diperoleh total pengaruh langsung country of origin terhadap keputusan pembelian sebesar 0,959 atau $(0,959 \times 100 \%) 95,9 \%$, Hal ini dikatakan bahwa terdapat hubungan saling pengaruh yang positif dan signifikan antara kedua variabel. Berdasarkan hasil tersebut, dapat diketahui bahwa country of origin berpengaruh terhadap keputusan pembelian tas gunung buatan Indonesia.

Berdasarkan uraian teori dan hasil penelitian yang telah dilakukan menggunakan analisis deskriptif dan verivikatif dengan menggunakan structural equation model (SEM) antara dimensi country of origin dampaknya terhadap keputusan pembelian.
Country of origin memiliki pengaruh yang positif terhadap keputusan pembelian tas gunung buatan Indonesia dengan nilai pengaruh langsung sebesar 0,959 atau $95.9 \%$, hasil ini diperoleh melalui uji model pada structural equation model melalui AMOS versi 20,0.

Dimensi yang membentuk country of origin memiliki pengaruh yang positif dalam mebentuk keputusan pembelian tas gunung buatan Indonesia. Dengan nilai masing-masing dimensi yaitu : 1) Country Beliefs sebesar 0,898, People Affect sebesar 0,894, Desired Interaction 0,868, Economic Development Level sebesar 0,785, Living Standard sebesar 0,600, Technology Developing Level sebesar 0,884, Product Quality sebesar 0,931, Self-Confident Level for Owning This Product sebesar 0,931, Product Reliability sebesar 0,891 hasil ini diperoleh melalui uji model pada structural equation model melalui AMOS versi 20,0.

Penelitian ini diharapkan dapat membantu bagi perusahaan agar para produsen tas gunung lokal khususnya pada perusahaan baru industri perlengkapan outdoor dapat meningkatkan nilai keputusan pembelian melalui strategi country of origin.

\section{DAFTAR PUSTAKA}

Al-Sulaiti, K. \& Baker, M. (1998). Country of origin effects: a literature review. Marketing Intelligence \& Planning, Vol. 16, No. 3: $150-99$.

Chen et all. 2012. Exploration of the differences in Taiwanese women's purchasing decisions towards luxury goods and general products. African Journal of Business Management Vol. 6(2), pp. 548-561,18 January, 2012

D, Z. D. S. P. H., Deilami, A., \& Ma, A. (2013). The Effect of Country of Origin Image on Brand Equity and Purchase Intention, 3(12), 52-61.

Chen et all. 2012. Exploration of the differences in Taiwanese women's purchasing decisions towards luxury goods and general products

Elliott, G. R. \& Cameron, R. C. (1994). Consumer perception of product quality and the countryof-origin effect. Journal of International Marketing, Vol. 2 No.2: 49-62

Ian Phau Vasinee Suntornnond, (2006),"Dimensions of consumer knowledge and its impacts on country of origin effects among Australian consumers: a case of fast-consuming product", Journal of Consumer Marketing, Vol. 23 Iss 1 pp. 34 - 42

Jim Blythe. 2013. Consumer Behaviour $2^{\text {nd }}$ Edition. Sage Publications

Jinm Byoungho dan George. 2013. "Consumer P_urchase Intention Toward Forign Brand Goods". Journal of Management Decision vol. 51 No. 2 pp. $434-450$

Jobber, David, \& Lancaster, Geoff. 2010. Selling and Sales Management. (8th Edition). England: Prentice Hall. 
Kaynak, Erdener \& Kara, Al. 2002." Consumer Perception of foreign Product : Analisys of Product Country Image and Ethnocentrism". Europan Journal of Marketing.Vol. 36 iss.7/8. Pp. 928-949

Keegan, Warren J \& Mark C. Green. Global Marketing $5^{\text {th }}$ Edition. New Jersey : Prentice Hall

Kotler, P and Armstrong, G. (2014). Principles of Marketing. New Jersey: Pearson Education.Inc

Kotler, Philip dan Keller, Kevin Lane. 2012. Marketing Management $14^{\text {th }}$ edition. New Jersey : Prentice Hall

Kumara, Samantha dan Chunhua, Kang. 2010. "Perception of Country Of Origin: An Approach to Identifying Expectations of Forigen Products". Journal of Brand Managemen. 17, 343-353

M. Sadiq Sohail. 2005. "Malaysian Consumers Evaluation of Product Made in Germany : The Country of Origin effect". Asia Pasific Journal of Marketing and Logistic. Vol. 17 Iss 1 pp 89-105

Maheswaran, Durairaj. 2006. "Country Of Origin Effect: Consumer Perceptions Of Japan in South East Asia", Working Paper Series

Maholtra, Narkesh K. 2009. Riset Pemsaran, Penerapan Terapan. Jakarta : Gramedia Pustaka Utama

Muchtar, Fatimah, Kingshott, Russel P. J., Wong, David \& Laksamana, Patria. (2012). A purchase intention model for foreign banks within Indonesia. International Journal of Bank Marketing, Vol. 30 No. 6: 452-464.

Carrigan Marylyn, Ahmad Attala. 2001. The myth of ethical consumer do ethics matter in purchase behavior. Journal of consumer marketing. Vol 18. No 7 pp 560-576 @ MCB University Press 0736-3761

Michael R. Solomon, Rebekkah Russel-Bennet, Josephine Previte. 2013. Consumer Behaviour: Buying, Having, Being 3rd Edition. Pearson Australia

Michael Solomon, Gary Bamossy. Soren Askegaard, Margaret K. Hogg. 2013.Consumer Behavior :A European Perspective $5^{\text {th }}$. New Jersey: Pearson Addison Wesley

Diamantopoulos, A., Schlegelmilch, B., \& Palihawadana, D. (2011). The relationship between country-of-origin image and brand image as drivers of purchase intentions: A test of alternative perspectives. International Marketing Review, 28(5), 508-524.

Heuscher, Z., Gilkey, D. P., Peel, J. L., \& Kennedy, C. A. (2010). The association of self-reported backpack use and backpack weight with low back pain among college students. Journal of Manipulative and Physiological Therapeutics, 33(6), 432-437.
Hu, X., Li, L., Xie, C., \& Zhou, J. (2008). The effects of country-of-origin on Chinese consumers' wine purchasing behaviour. Journal of Technology Management in China, 3(3), 292-306.

Ihya Ulumuddin, Lili Adi Wibowo, dan A. B. (2013). Pengaruh brand feelings terhadap loyalitas tamu di sheraton senggigi beach resort lombok, (2), 607-618.

Jiménez, N., \& Martín, S. S. (2012). Emerging Markets Commerce: The Role of Country-ofOrigin and Animosity in Purchase Intention, 7(17), 34-42.

Lili Adi Wibowo dan Yeni Yuniawati. (2007). The Influence of Tourist Product Attribute and Trust to Tourist Satisfaction and Loyalty A Study of Mini Vacation in Bandung Oleh: Journal of Chemical Information and Modeling, 53(9), 1689-1699.

Lin, L. Y., \& Chen, C. S. (2006). The influence of the country-of-origin image, product knowledge and product involvement on consumer purchase decisions: an empirical study of insurance and catering services in Taiwan. Journal of Consumer Marketing, 23(5), 248265.

Lisnawati, L. D. dan. (2016). EKUITAS MEREK DISPOSABLE DIAPER MEREK SWEETY ( SURVEI PADA. Journal of Business Management and Enterpreneurship Education, 1(1), 158-173.

Piron, \& Francis. (2000). Consumers' perceptions of the country-of-origin effect on purchasing intentions of (in)conspicuous products. Journal of Consumer Marketing, 17(4), 308321.

Rahayu, A., \& Anggarini, G. (2009). KEPUTUSAN PEMBELIAN PRODUK AUDIO SONY, $12-95$.

Wibowo, L. A. (2014). ANALISIS FAKTORFAKTOR DOMINAN DALAM PEMBENTUKAN CREATIVE TOURISM DAN PENGARUHNYA TERHADAP KEPUTUSAN BERKUNJUNG (Survei terhadap Wisatawan Mancanegara Asal Belanda, Jerman dan Perancis yang berkunjung ke D.I. Yogyakarta), (2), 823842.

Narissara Parkvithee Mario J. Miranda, (2012), "The interaction effect of country-of-origin, brand equity and purchase involvement on consumer purchase intentions of clothing labels", Asia Pacific Journal of Marketing and Logistics, Vol. 24 Iss 1 pp. 7 - 22

O.C. Ferrell, Michael D. Hartline. 2011. Marketing Strategy 5th Edtition. South-Western Cengage Learning 5191 Natorp Boulevard Mason, OH 45040 USA 
Peter, Paul J. dan Olson, Madison Jerry. 2010. Consumer Behavior and Marketing Strategy. New Jersey : McGraw-Hill

Prasetijo, Ristiyanti dan Ihalauw, John J.O.I. 2005. Prilaku Konsumen. Yogyakarta: Andi

Rezvani, Samin, et.al. 2012. " A Conceptual Study on the COO effect on Consumer Purchase Intention. Asian Journal of Social Science.Vol.8, No. 12. 2012. 205-215

Schifman, Leon G dan Kanuk, Leslie. 2008. Prilaku Konsumen edisi ketujuh: Edisi ketujuh, Pearson Prentice Hill

Setiadi, Nugroho J. 2003. Perilaku Konsumen. Kencana. Jakarta.

Simamora, Bilson. 2002. Panduan Riset Perilaku

Konsumen.Jakarta : Gramedia

Solomon, Michael R. 2011. Consumer Bahavior : Buying, Having, and Being. New jersey : Prentice Hall

Siregar. 2013. Metode Penelitian Kuantitatif. BukuBeta

Sugiyono. (2013). Metode Penelitian Kuantitatif Kualitatif dan $R \& D$. Bandung: Alfabeta

Xiaoling Hu Leeva., Leeva Li., Charlene Xie., Jun Zhou. 2008. "The Effect of Country Of Origin on Chinese consumers Wine
Purchasing Behaviour". Journal Technology Management in China. Vol. 3 Iss 3 pp. 292-306

Simamora, Bilson. Sar, Hasrini,dan Heryanto, Joni 2008. "The Influence of Product and NonProduct Dimension and Country Of Origin Dimension on Brand Image". Jurnal Manajemen Teknologi. 7, (2), 105-124

Wang Xuehua \& Zhilin Yang. 2011, Standardization or Adaptation in International Advertising Strategies: The Roles of Brand Personality and Country of Origin Image, Asian Journal of Business Research Vol.1 no.2 p. 28

Wu, Kuang-Wen dan Wu, Kung-Chang. 2008. “The Effect on Purchase Intention Through The Dimensions of Brand Image and Brand of Origin". Electronic Theses Harvestable and Extensible System.1-3.

Yassin, N. M,, Noor, M. N. dan Mohammad, 0. 2008. Does Image of Country of Origin Matter to Brand Equity? 1-13

Yeong Neoh Chee. 2004. "Brand Name and COO effect on Consumer in Malaysia". Master of Business 